\title{
Nilai Estetik dan Nilai Filosofis pada Qiu Qian di Kelenteng Perempuan Vihara Buddhi Bandung
}

\author{
Tjutju Widjaja ${ }^{1}$, Ira Adriati ${ }^{2}$, Setiawan Sabana ${ }^{3}$ \\ Program Studi Seni Rupa, Fakultas Seni Rupa dan Desain, Institut Teknologi Bandung, \\ Jalan Ganeca 10, Bandung, 40132, Indonesia \\ 1tjutjuw@gmail.com
}

Vihara Buddhi, atau yang populer dengan sebutan Kelenteng Perempuan adalah tempat ibadah masyarakat Tionghoa yang unik yang menganut ajaran Sanjiao atau Tridharma (tiga ajaran). Sanjiao atau Tridharma (Tiga Ajaran) adalah perwujudan sinkretisme dari tiga aliran utama kepercayaan masyarakat Tionghoa yakni: Buddhisme, Konfusianisme dan Taoisme. Vihara Buddhi berlokasi berlokasi di Jl. Cibadak 281 Bandung dan dikelola oleh sekelompok pendeta perempuan yang dikenal dengan sebutan Zhai Ji. Qiu Qian adalah salah satu artefak yang terdapat di Kelenteng Perempuan yang digunakan sebagai benda ritual. Penelitian ini bertujuan untuk mengungkap nilai estetik dan nilai filosofis pada Qiu Qian di Vihara Buddhi Bandung. Teori yang digunakan adalah teori nilai seni dan estetika mitis dari Jakob Sumardjo. Metode yang digunakan dalam penelitian ini adalah metode penelitian kualitatif: Studi pustaka, observasi, wawancara, dokumentasi dan purposive sampling. Hasil penelitian menunjukan bahwa nilai estetik Qiu qian terletak pada teknik pembuatan dekorasi yang diaplikasikan pada Qian Tong atau wadah penyimpanan batang Qiu Qian. Dekorasi dibuat secara manual dengan tangan menggunakan teknik ukiran berjenis ukiran cembung dan ukiran sedang. Nilai filosofis pada Qiu Qian terletak pada simbol-simbol yang menjadi objek dekorasi pada Qian Tong. Simbol-simbol yang diukir pada Qian Tong merepresentasikan nilai-nilai yang merupakan prinsip dalam Buddhisme.

Kata kunci : nilai estetik, nilai filosofis, kelenteng perempuan, qiu qian

Vihara Buddhi, or popularly known as the Female Temple, is a unique place of worship for Chinese people who adhere to the teachings of Sanjiao or Tridharma (three teachings). Sanjiao or Tridharma is a manifestation of syncretism from the three mainstreams of Chinese beliefs: Buddhism, Confucianism and Taoism. Vihara Buddhi is located on Jl. Cibadak 281 Bandung and managed by a group of priestesses known as Zhai Ji. Qiu Qian is one of the artefacts found in the the Female Temple which is used as a ritual object. This study aims to reveal the aesthetic and philosophical values of Qiu qian at the Buddhist Temple in Bandung. The theory used is the theory of the artistic value and mythic aesthetics of Jakob Sumardjo. The method used in this research is qualitative research methods: Literature study, observation, interviews, documentation and purposive sampling. The results show that the aesthetic value of Qiu Qian lies in the decoration making technique that is applied to Qian Tong, a storage container for Qiu Qian sticks. Decoration is made manually by hand using convex engraving and medium engraving. The philosophical value of Qiu Qian lies in the symbols that are the objects of decoration in Qian Tong. The symbols carved on Qian Tong represent the values which are the principle in Buddhism.

Keywords: aesthetic value, philosophical value, female temple, qiu qian

Proses Review : 1 - 20 Mei 2020, Dinyatakan Lolos: 29 Mei 2020 


\section{PENDAHULUAN}

San Jiao atau Tiga Ajaran adalah manifestasi dari sinkretisme dari tiga keyakinan utama orang-orang Tiongkok: Buddhisme, Konfusianisme, dan Taoisme (Kwa Tong Hay, 2013: 20). Semangat orang-orang Tionghoa telah lama selaras dengan spiritualitas modern, yang melihat satu tujuan meskipun keyakinan berbeda. Dalam bahasa Mandarin, ini disebut三而一也 ("san er yi ye"): "tiga adalah satu", atau 含三为一 ("han-san wei-yi"): "satu yang terdiri dari tiga". Ketiga aliran tersebut memiliki tujuan yang sama walaupun terdapat sedikit perbedaan. Pengaruh ajaran Sanjiao di Tiongkok perlahan menghilang seiring dengan paham Komunisme yang dijadikan asas ideologi negara tersebut. Namun ajaran Sanjiao tetap dipraktikkan di negara berpenduduk Tionghoa perantauan yakni di Taiwan, Hong Kong, Macau, Singapura dan Indonesia. Kini di Indonesia, Sanjiao resmi disebut sebagai Tridharma, sedangkan Kelenteng diakui sebagai lembaga keagamaan yang disebut sebagai Tempat Ibadah Tri Dharma (TITD) (Tanggok, 2017: 27). Penetapan tersebut diberlakukan oleh Menteri Agama R.I pada 19 November 1979.

Istilah "Kelenteng" merupakan istilah khas bahasa Indonesia yang khusus untuk menyebut tempat ibadah yang digunakan oleh orang Tionghoa di Indonesia. Menurut Sugiri Kustedja (2017: 3), istilah Kelenteng hanya ada dalam bahasa Indonesia, tidak ditemukan di Tiongkok sendiri ataupun perbendaharaan bahasa Tionghoa. Menurut beberapa ahli bahasa, istilah Kelenteng berasal dari bunyi "tengteng" yang terdengar dari dalam bangunan tersebut pada waktu diadakannya upacara sembahyang. Suara ini berasal dari lonceng-lonceng yang ditabuh pada waktu pembacaan parita atau pada saat pundak upacara (Kwa Tong Hay, 2013: 2). Kelenteng ini ada juga yang menamakannya dengan istilah "pekong". Kelenteng pada umumnya dibangun atas dasar swadaya bersama sekelompok warga, pada umumnya kelompok warga yang memiliki kesamaan marga dan tempat tinggal (Tanggok, 2017: 27).

Situasi politik di Indonesia sangat berpengaruh terhadap eksistensi Kelenteng sebagai tempat ibadah orang Tionghoa. Pada masa presiden RI yang pertama, Soekarno, pemerintah telah mengakui Konghucu sebagai agama di samping agama-agama lain yang diakui di Indonesia yakni, Islam, Kristen, Katolik, Hindu dan Buddha. Pada saat pemerintahan yang dijalankan oleh presiden Soeharto, awalnya agama Konghucu masih diakui, namun pada era 70-an, pemerintah mencabut pengakuannya terhadap Konghucu sebagai agama yang diakui di Indonesia. Keputusan pemerintah ini merupakan imbas dari peristiwa G30S/PKI. Akibatnya banyak Kelenteng yang terancam ditutup secara paksa. Solusi praktis dari permasalahan ini adalah dengan menyediakan tempat untuk menghormati Buddha di dalam Kelenteng, dengan demikian surat izin tempat beribadah dapat dikeluarkan dengan nama Vihara, hal ini umumnya terjadi di Provinsi jawa Barat. Sedangkan di sebagian provinsi Jawa Timur dan Jawa Tengah, nama Kelenteng berubah menjadi Tempat Ibadah Tridharma (TITD) (Kustedja, 2017: 3).

\section{Kelenteng Perempuan Vihara Buddhi dan Zhai Ji}

Salah satu Kelenteng yang memakai nama Vihara, adalah Vihara Buddhi yang berlokasi di Jl. Cibadak 281 Kota Bandung, Provinsi Jawa Barat. Vihara Buddhi merupakan salah satu kelenteng yang unik, karena memiliki nama lain yang dikenal dengan istilah "Kelenteng Perempuan". (Selanjutnya dalam tulisan ini penulis akan menggunakan istilah Kelenteng Perempuan ini). Yang dikelola oleh sekelompok perempuan Hakka yang termarginalkan sejak bayi. Zhai Ji dalam dialek Hakka artinya adalah "kakak perempuan yang vegetarian", adalah sekelompok pendoa perempuan dari subetnis Hakka dari Meizhou. Sehingga dapat dikatakan kelompok pendoa ini khas dari Meizhou. Mereka dipengaruhi oleh Buddhisme, Taoisme dan Konfusius tapi unsur Buddhisme lebih kental sehingga sering juga disebut Buddhisme rakyat. Kelompok pendo'a ini tinggal dalam biara yang disebut "an" sehingga bisa disebut biarawati juga walau tidak terikat dengan institusi agama Buddha resmi.

Para Zhai Ji ini lahir pada medio akhir abad ke 19. Dimana saat itu Tiongkok sedang terpuruk karena masalah candu, agresi negara-negara Barat, korupsi merajalela, ekonomi yang runtuh. Sehingga masyarakat jelata menderita dan korban terparah adalah kaum perempuan. Mereka menjadi obyek penderita yang berkepanjangan dalam kondisi negara yang terpuruk itu. Kaum perempuan sub etnis Hakka juga menderita bahkan paling menderita karena selain mereka tidak dihargai juga sering kali harus membanting tulang demi keberlangsungan hidup keluarga mereka. Hal lainnya adalah kekerasan dalam rumah tangga sering mendera mereka. Sehingga ada bhiksu Xianghua yang mengajari perempuan-perempuan yang tersisihkan itu, baik kaum janda, anak balita, ibu rumah tangga yang disia-siakan.

Mereka kemudian dibekali dengan kemampuan sastra, ritual dan lima ilmu dasar wushu untuk melayani masyarakat. Baik untuk masalah kehidupan hingga alam kematian. Bahkan dalam beberapa kasus mereka dipercaya memiliki kemampuan untuk berhubungan dengan dunia arwah. Kemampuan-kemampuan itu membuat mereka menjadi lebih tinggi derajatnya dari kaum pria kebanyakan sehingga sebutan untuk mereka adalah $J i$ atau ma. Kemampuan itu tidak selalu terkait dengan hal-hal yang bersifat supra natural atau ritual saja tapi juga terkait dengan kemampuan mereka dalam surat menyurat dan baca tulis. Suatu kemampuan yang cukup langka pada masa itu apalagi kaum perempuan yang menguasai sastra.

Kelenteng sebagai tempat ibadah para penganut Sanjiao memiliki berbagai artefak yang digunakan dalam berbagai prosesi ritual yang dipimpin oleh para Zhai Ji. Artefak-artefak tersebut berupa lukisan, patung, azimat, dan benda 
ritual yang memiliki fungsi-fungsi yang spesifik yang berkaitan dengan jenis ritual tertentu. Artefak sebagai produk dan representasi dari kepercayaan tertentu dipastikan mengandung nilai estetika dan nilai filosofis. Penelitian ini bertujuan untuk menganalisis nilai estetika dan nilai filosofi pada salah satu artefak yang berfungsi sebagai benda ritual yang berada di dalam Vihara Buddhi yakni, Qiu Qian.

\section{Landasan Teori}

\section{Nilai Ekstrinsik dan Nilai Intrinsik Seni}

Setiap karya seni memiliki dua nilai seni, yakni nilai intrinsik dan nilai ekstrinsiknya. Nilai intrinsik seni berkaitan dengan unsur-unsur rupa dalam sebuah karya, sedangkan nilai ekstrinsik berkaitan dengan gagasan, perasaan ataupun konsep yang melatarbelakangi pembuatan karya tersebut. Pembagian nilai ini mengacu kepada teori Jakob Sumardjo (2000: 169), dalam bukunya yang berjudul "Filsafat Seni" :

“Aspek Intrinsik yakni: Aspek intrinsik dibentuk oleh medium atau material seninya. Unsur seni rupa terdiri atas semua aspek yang dimiliki oleh bahan utamanya yakni cat lukis dan bidang gambarnya. Pada seni sastra bahan utamanya adalah bahasa yang membentuk imaji atau gambaran. Pada seni musik, materialnya terdapat dalam bunyi dan suara. Tetapi penggunaan bahan material seni tadi dilandasi oleh niat ekstrinsiknya, yakni gagasan, pikiran dan perasaan seniman. Jadi tak mungkin memisahkan aspek intrinsik dari aspek ekstrinsiknya. Unsur ekstrinsik dalam seni (gagasan dan perasaan) hanya dapat ditangkap oleh orang lain melalui perwujudan intrinsiknya"

Qiu Qian akan dianalisa dengan teori tentang nilai estetika yang dibagi ke dalam nilai intrinsik dan nilai ekstrinsik. Nilai intrinsik pada Qiu Qian mencakup setiap aspek rupa seperti dimensi, material, gaya dan tehnik serta komposisi visual yang digunakan dalam pembuatan Qiu Qian sehingga akan didapat simpulan berupa nilai estetikanya . Nilai ekstrinsik pada Qiu Qian meliputi sejarah, mitologi dan posisi Qiu Qian sebagai benda ritual kepercaryaan masyarakat Tionghoa sehingga akan didapat simpulan berupa nilai-nilai filosofis yang terkandung dalam Qiu Qian tersebut.

\section{Lingkup Dasar Religius Estetika Mitis}

Artefak yang terdapat di Vihara Buddhi sebagian besar memiliki fungsi sebagai atribut ritual keagamaan, demikian halnya dengan Qiu Qian yang akan diteliti dalam tulisan ini. Oleh karenanya, dalam mengungkap nilai-nilai estetika yang terdapat pada artefak, penulis akan mengacu kepada dasar religius estetika mitis, sebuah wacana estetika dari Jakob Sumardjo (2000: 319) dengan pertimbangan bahwa Qiu Qian yang berada di Vihara Buddhi merupakan artefak hasil budaya mitis. Budaya mitis ini didefinisikan oleh Jakob Sumardjo dengan membandingkannya dengan Budaya modern:
"Cara berpikir budaya mitis berbeda dengan cara berpikir modern yang ontologis. Pada budaya mitis, manusia justru bersikap menyatu dengan alam di luar dirinya. Hidup ini merupakan kesatuan maha besar, antara manusia dengan masyarakat, antara manusia dengan alam, antara manusia dengan roh yang gaib, antara manusia dengan seluruh tata kosmos semesta ini. Manusia harus menyelaraskan diri dengan kosmos tadi kalau mau selamat di dunia fana ini. Manusia menyatukan dirinya dengan objek di luar dirinya, dan dari sana menemukan jati dirinya."

Lalu mengenai logika budaya mitis Soemardjo (2000: 320) menjelaskan bahwa Logika mitis berbeda dengan logika ontologis. Logika mitos dan dongeng rakyat berbeda dengan logika novel modern. Dalam logika mitis, adalah wajar apabila dalam keringat dewa yang menetes dari tubuhnya dapat menjelma menjadi seorang manusia. Itu karena di dunia para dewa, di dunia sana, segalanya omnipoten, serba mungkin, sedang dunia manusia bersifat fana...". Jakob Soemardjo (2000: 321) juga menjelaskan perihal estetika mitis:

"Dunia mitis memiliki estetikanya sendiri yang berbeda dengan estetika dunia ontologis. Pertunjukan seni pantun di tanah Sunda bukan sekedar pertunjukan berupa seni tutur para raja dan pahlawan Kerajaan Pajajaran Lama, tetapi merupakan upaya menghadirkan para tokoh mitos dari dunia 'sana' ke dunia 'sini'. Peristiwa penceritaan pantun bukan sekedar estetika lakon, melainkan peristiwa kesatuan kosmis secara religius. Kegagalan seni pantun, misalnya, bukan sekedar kegagalan estetis. Yang lebih gawat adalah kegagalan religius yang akibat-akibatnya harus ditanggung oleh masyarakat sewaktu-waktu"

Estetika Mitis melihat artefak sebagai satu kesatuan dengan kosmologi yang identik dengan keyakinan seniman atau kepercayaan yang dianut dalam lingkup lingkungan tempat karya tersebut diciptakan atau difungsikan.

Penelitian ini berkontribusi umumnya terhadap pelestarian kebudayaan asli masyarakat Tionghoa di Indonesia, khususnya bagi masyarakat Tionghoa di Indonesia yang menganut agama Tridharma. Hasil dari penelitian ini dapat berkontribusi sebagai referensi mengenai artefak yang berfungi sebagai benda ritual yang umumnya terdapat di dalam Kelenteng sebagai tempat ibadah penganut agama Sanjiao, karena referensi mengenai hal ini tidak banyak ditemukan. Penelitian ini juga dapat berfungsi sebagai pengetahuan yang berkaitan dengan identitas budaya masyarakat asli Tionghoa di Indonesia yang layak dilestarikan setelah upaya rezim orde baru untuk menghilangkan kebudayaan dan identitas asli masyarakat Tionghoa di Indonesia.

\section{METODE PENELITIAN}

Penelitian ini menggunakan metode penelitian kualitatif 


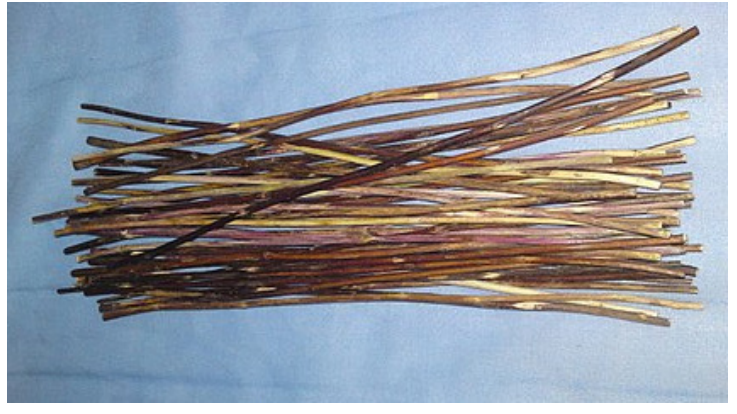

Gambar 1. Batang rumput liar yang dikeringkan yang dikeringkan sebagai Qian

(sumber: https://en.wikipedia.org/wiki/I_Ching)

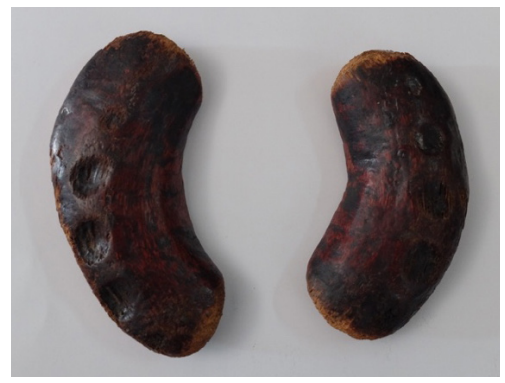

Gambar 2. Jiao Bei/Sinkaw di Vihara Buddhi Bandung (sumber: survey, 2019)

yang terdiri dari studi pustaka, observasi, wawancara, dokumentasi dan purposive sampling. Penelitian dilakukan secara deskriptif dengan menganalisis berbagai macam data dan literatur menjadi suatu teori serta data hasil observasi yang mendukung penelitian. Jenis data dalam penelitian ini didapat melalui dua cara yakni, studi literatur dan observasi data mengenai Qiu Qian di Vihara Buddhi Bandung. Data literatur meliputi agama, estetika, sejarah, mitologi dan proses kreasi. Studi literatur yang dilakukan adalah melalui buku dan jurnal. Observasi akan dilakukan untuk mengumpulkan data tentang Qiu Qian.

\section{ANALISIS DAN INTEPRETASI DATA}

\section{Latar Belakang Sejarah Qiu Qian}

Cangianto (2017) menjelaskan bahwa masyarakat Tionghoa di Indonesia dan penganut Sanjiao pada umumnya tidak mengetahui secara jelas mengenai latar belakang sejarah Kiu Ciam / Qiu Qian (求籤), sebagian menyebutnya dengan Chiamsi (籤詩). Cangianto (2017) berasumsi bahwa Qiu Qian merupakan tehnik ramalan dari zaman purba. Situs www.wikipedia.com (2019) menjelaskan bahwa praktik Qiu Qian dimulai pada saat dinasti Jin (11151234). Pada zaman dahulu di Tiongkok ada tiga metode dan alat peramalan yakni: 1 . Mengamati langit dan perubahan alam serta manusia, 2. Menggunakan bahan ya;ng berasal dari binatang, 3. Menggunakan bahan dari tumbuhan. Arti dari Chiam / Qian sendiri memiliki lebih dari satu definisi, Tanggok (2017: 98) dan Cangianto (2017) mendefinisikannya sebagai batang yang terbuat dari bam-

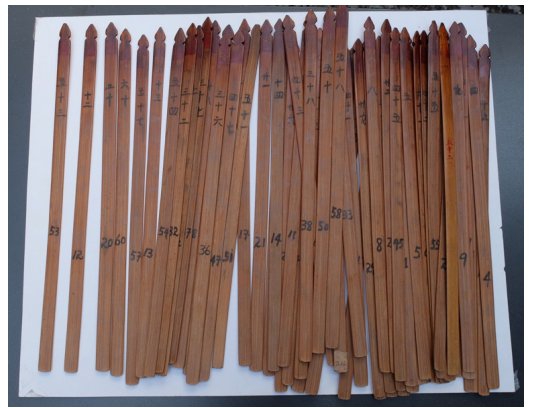

Gambar 3. Qiu Qian di Vihara Buddhi Bandung (sumber: survey, 2019)

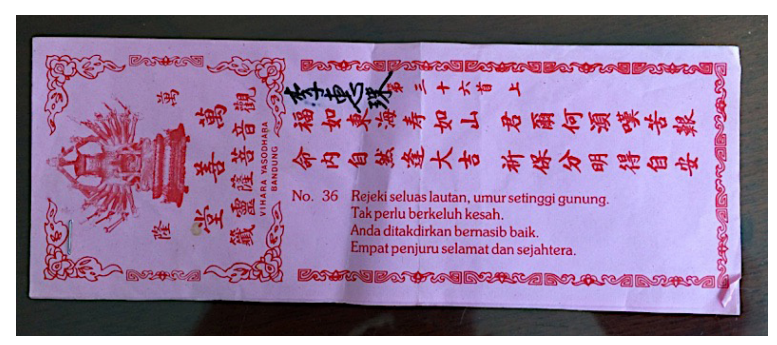

Gambar 4. Kertas Chiamsi di Vihara Buddhi Bandung (sumber: survey, 2019)

bu, sedangkan Qian Ma (2005: 125) mendefinisikannya sebagai batang rumput liar (gambar 1).

Qian digunakan di dalam ritual untuk meminta jawaban dari Dewa dan Dewi atas sebuah pertanyaan yang diajukan oleh seseorang. Chiamsi adalah kertas berisi syair-syair sebagai hasil dari ritual Qiu Qian (Cangianto, 2017). Syairsyair ini dipercaya merupakan jawaban yang diminta dari Dewa atas pertanyaan yang diajukan. Syair-syair tersebut kemudian diinterpretasi oleh para pemuka agama di Kelenteng tempat ritual tersebut diselenggarakan. Ritual Chiamsi tidak dapat dipisahkan dengan Jiao Bei/Sinkaw, sepasang blok yang terbuat dari kayu menyerupai bentuk bulan sabit (gambar 2).

Deskripsi lengkap mengenai ritual Chiamsi adalah sebagai berikut (Gondomono, 2017: 98-99):

"Sebagaimana layaknya orang China, orang Hakka di Singkawang juga percaya pada Chiamsi (batangan bambu yang digunakan untuk melihat keberuntungan atau ramalan) dan sinkaw (terbuat dari kayu atau tembaga yang menyerupai pinang dibelah dua, fingsinya untuk membernarkan ramalan Chiamsi). Setelah sembahyang di Pekong atau Kelenteng, mereka biasanya mengambil Chiamsi dan Sinkaw di atas altar sembahyang. Kemudian mereka kembali duduk bersimpuh di depan altar sembahyang. Bisa duduk, tapi bisa juga berdiri, mereka kemudian mengguncang batangan Chiamsi yang ada di kaleng. Setelah batangan Chiamsi keluar, orang itu mengambil dua buah 


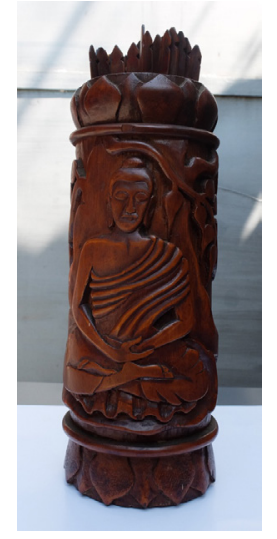

Gambar 5. Qian Tong terisi penuh di Vihara Buddhi Bandung (sumber: survey, 2019)

sinkaw dan melambungnya setinggi 1 meter dan dibiarkan jatuh di lantai. Jika jatuh dalam keadaan tengkurap dan terlentang, maka ramalan yang tertulis di salah satu bambu tadi disetujui oleh dewa.Namun, jika kedua Sinkaw jatuh dalam keadaan tengkurap atau dalam keadaan terbuka, berarti dewa tidak setuju atas Chiamsi yang telah didapatkan tadi. Jika ini terjadi, harus dilakukan pengguncangan ulang. Hal yang sama juga dilakukan pada Sinkaw. Apabila antara Chiamsi dan Sinkaw sudah cocok, maka batang Chiamsi yang diperoleh dicocokan dengan kertas Chiamsi. Di kertas berukuran $5 \mathrm{~cm}$ x $20 \mathrm{~cm}$ sudah tertulis terjemahan dari batangan Chiamsi. Apa yang harus kita lakukan , sesuai dengan pertanyaan kita, sudah tertulis di kertas tersebut dan ini bisa dijadikan pedoman bagi pemuja untuk bertidak dalam kehidupan sehari-hari."

\section{Qiu Qian di Vihara Buddhi Bandung.}

Qiu Qian di Vihara Buddhi, serupa dengan umumnya Qiu Qian yang terdapat di Kelenteng lain dalam hal kelengkapannya. Istilah Qiu Qian dalam penelitian ini merujuk pada satu set batang / stik Qiu Qian sekaligus tempatnya (Qiu Tong). Batang Qiu Qian di Vihara Buddhi berjumlah 60 batang, masing-masing memiliki tinggi $26 \mathrm{~cm}$ dan lebar $1 \mathrm{~cm}$ (Gambar 3). Qiu Qian di Vihara Buddhi terbuat dari bambu. Pada masing-masing batang tertulis nomor yang berbeda yang ditulis dengan penomoran Arab dan Mandarin. Masing-masing nomor berkorespondensi dengan nomor pada kertas Chiamsi.

Pada masing masing batang Qiu Qian terdapat nomor untuk dicocokan dengan kertas Chiamsi (Gambar 4). Seluruh batang Qiu Qian disimpan dalam sebuah wadah berbentuk tabung tanpa tutup yang disebut Qian Tong (簽筒) yang memiliki dimensi tinggi $27 \mathrm{~cm}$ dan berdiameter $9 \mathrm{~cm}$ (gambar 5). Qian Tong di Vihara Buddhi terbuat dari kayu dengan dekorasi seni ukir mengelilingi seluruh sisinya.

Nilai Estetik dan Nilai Filosofi Qiu Qian di Vihara Buddhi Bandung

Nilai Estetik

Bentuk dan material pada batang Qiu Qian dibuat berdasar-

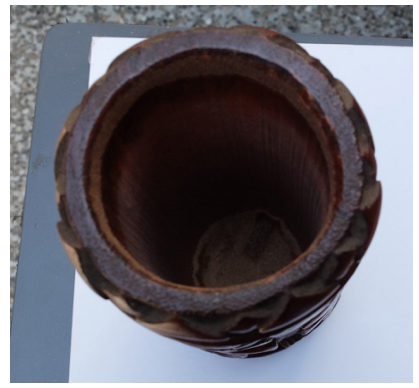

Gambar 6. Qian Tong tampak atas, perbandingan kedalaman objek ukiran mencapai setengah dari bentuk utuh kayu. (sumber: survey, 2019)

kan fungsi dari Qiu Qian yang digunakan untuk Chiamsi. Cangianto (2017) berasumsi bahwa Qiu Qian berasal dari salah satu dari tiga metode meramal pada zaman purba, yakni metode meramal menggunakan tumbuhan (batang rumput). Material batang Qiu Qian yang populer saat ini adalah yang terbuat dari bambu, bentuk batang merupakan bentuk yang berasal dari masa Qiu Qian_masih terbuat dari batang rumput. Qian Tong di Vihara Buddhi merupakan tempat disimpannya batang Qiu Qian. Qian Tong memiliki dimensi tinggi $27 \mathrm{~cm}$ dan berdiameter $9 \mathrm{~cm}$. Qian Tong terbuat dari kayu jati berhiaskan ukiran dengan motif figur Buddha dalam posisi duduk bermeditasi. Di atas figur Buddha terdapat ukiran berbentuk potongan ranting dan daun, jika melihat posisi meditasi Buddha yang duduk dan konteks kisah Buddha, maka ukiran daun dan ranting tersebut sangat mungkin merepresentasikan pohon Boddhi. Sisi lain dari Qian Tong dihiasi dengan ukiran berbentuk simbol - simbol populer dalam agama Buddha yakni: Mandala, Swastika dan bunga lotus.

Dekorasi pada Qian Tong merupakan karya relief yang diukir di atas kayu. Dawan (2019) mendefinisikan seni ukir sebagai suatu kegiatan mengolah permukaan suatu objek trimatra (tiga dimensi) dengan membuat perbedaan ketinggian dari permukaan tersebut sehingga menghasilkan sebuah produk karya seni yang memiliki bentuk permukaan tidak rata. Merujuk pada Bastomi dalam Dawan (2019), terdapat enam jenis seni ukir yakni: Jenis ukiran cembung, jenis ukiran cekung, jenis ukiran susun, jenis ukiran garis, jenis ukiran takokan dan jenis ukiran tembus (krawangan). Berdasarkan tinggi rendahnya ukiran yang dihasilkan, Dawan (2019) membaginya menjadi empat jenis, yakni: Ukir rendah, ukir sedang, ukir tinggi, dan ukir cekung. Dekorasi pada Qian Tong termasuk dalam ukiran cembung dan ukiran sedang. Dekorasi tersebut termasuk dalam ukiran cembung karena objek gambar diukir sehingga muncul ke luar permukaan. Jarak objek ukiran yang timbul adalah separuh bentuk kayu utuhnya, oleh karenanya termasuk ukiran sedang. Gaya ukiran pada dekorasi Qian Tong Vihara Buddhi tidak mengacu pada gaya seni ukir tertentu. 


\section{Nilai Filosofis}

Nilai filosofis pada Qiu Qian Vihara Buddhi Bandung terletak pada makna dari simbol-simbol yang menjadi unsur dekoratif dari Qian Tong, yakni:

1. Figur Buddha bermeditasi di bawah pohon Boddhi, representasi kesempurnaan spiritual.

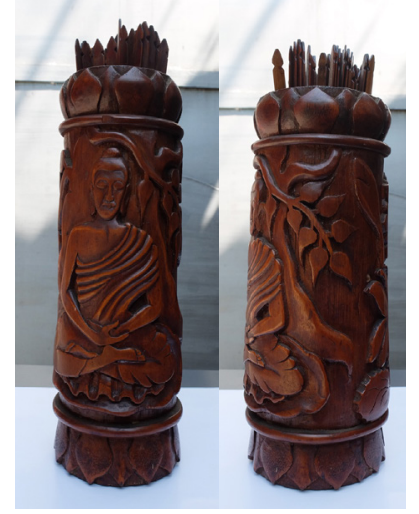

Gambar 7. Sosok Buddha sedang bermeditasi di bawah pohon Boddhi

(sumber: survey, 2019)

Gerakan tangan atau mudra dalam patung Buddha dikenal sebagai Dhyana Mudra, Samadhi atau Yoga Mudra. Gerakan ini telah digunakan oleh para yogi untuk meditasi dan berkonsentrasi. Mudra digunakan oleh Buddha selama meditasi terakhir di bawah 'pohon boddhi.' Ini menandakan pencapaian kesempurnaan spiritual (www.owlcation. com).

2. Mandala sebagai representasi keharmonisan yang abadi.

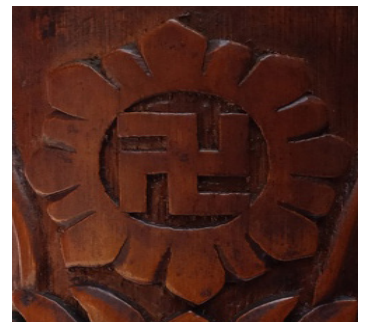

Gambar 8. Mandala mengelilingi simbol Swastika (sumber: survey, 2019)

Situs wikipedia.com (2019) menjelaskan bahwa mandala berasal dari bahasa sanskerta yang berarti lingkaran. Mandala merupakan simbol yang berasal dari agama Buddha aliran Mahayana. Mandala merepresentasikan keharmonisan yang abadi. Sifat keabadian identik dengan bentuk lingkaran pada mandala yang tidak memiliki titik awal dan titik akhir.

3. Swastika sebagai representasi kebaikan / jejak kaki Buddha.

Secara etimologis, definisi swastika, dikutip dari laman wikipedia.com (2019) adalah "Kata Swastika terdiri dari kata Su yang berarti baik, kata Asti yang berarti adalah dan akhiran Ka yang membentuk kata sifat menjadi kata benda. Sehingga lambang Swastika merupakan bentuk simbol atau gambar dari terapan kata Swastyastu (Semoga dalam keadaan baik)". Swastika dalam Buddhisme merupakan simbol dari kebaikan, keberuntungan, pertanda baik dari jejak kaki sang Buddha. Swastika adalah simbol aniconic dari Buddha di beberapa kebudayaan Asia.

4. Bunga lotus (padma) sebagai representasi dari kemurnian tubuh, ucapan dan pikiran.

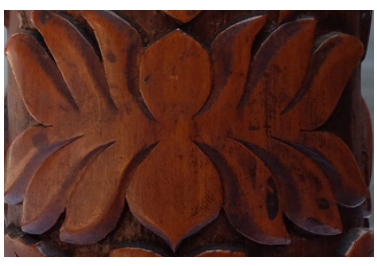

Gambar 9. Simbol padma pada Qian Tong Vihara Buddhi Bandung (sumber: survey, 2019)

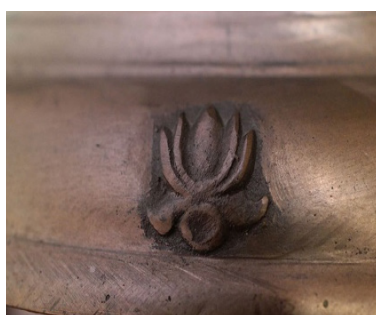

Gambar 9. Simbol padma pada salah satu lonceng Kuil. (sumber: www.wikipedia.com, 2019)

Dalam Buddhisme, bunga lotus merupakan simbol dari kemurnian tubuh, ucapan, dan pikiran. Simbol dari nilai agama Buddha tersebut berdasarkan fakta bahwa bunga lotus berkembang indah walaupun tumbuh di atas lumpur yang kotor. Lumpur merupakan simbol dari keterikatan terhadap dunia dan nafsu. Sifat dari bunga lotus yang tidak menyerap air pada permukaan bunganya merupakan simbol dari ajaran Buddha yang melarang pemeluknya terserap ke dalam nafsu duniawi (www.wikipedia.com, 2019).

\section{SIMPULAN}

Nilai estetik pada Qiu Qian Vihara Buddhi Bandung terletak pada teknik pembuatan dekorasi yang diaplikasikan pada Qian Tong atau wadah penyimpanan batang Qiu Qian. Dekorasi dibuat secara manual dengan tangan menggunakan teknik ukiran berjenis ukiran cembung dan ukiran sedang. Nilai filosofis pada Qiu Qian terletak pada simbol-simbol yang menjadi objek dekorasi pada Qian Tong. Simbol-simbol yang diukir pada Qian Tong merepresentasikan nilai-nilai yang merupakan prinsip dalam Buddhisme. Ritual Chiamsi bukan berasal dari ajaran Buddha, tapi Qiu Qian Buddhi Bandung penuh dengan simbol-simbol Buddhisme. Hal tersebut dikarenakan Vihara Buddhi Bandung merupakan rumah ibadah bagi penganut agam 
Sanjiao yang merupakan sinkretisme dari Taosime, Konfusianisme dan Buddhisme.

\section{DAFTAR RUJUKAN}

Gondomono. (2013), Manusia dan kebudayaan Han, Penerbit Buku Kompas, Jakarta.

Kustedja, Sugiri. (2017), Klenteng Xie Tian Gong (Hiap Thien Kiong, Vihara Satya Buddhi) \& Tiga Luitenant Tionghoa di Bandung, Bina Manggala Widya, Bandung.

Kwa Tong Hay. (2013), Dewa Dewi Kelenteng, Bina Manggala Widya, Bandung.

Sumardjo, Jakob. (2000), Filsafat seni, Penerbit ITB, Bandung.

Tanggok, M Ikhsan. (2017), Agama dan kebudayaan orang Hakka di Singkawang, Penerbit Buku Kompas, Jakarta.

Qian Ma. (2005), Women in Traditional Chinese Theater: The Heroine's Play, University Press of America, Lanham, Maryland.

Cangianto, Adrian. (13 Januari 2016). Menjelajahi misteri ciamsi dan pwa pwee. http://web.budaya-tionghoa. net/index.php/item/3812-menjelajahi-misteri-ciamsi-dan-pwa-pwee-bag-1

Cangianto, Adrian. (22 April 2016). Menjelajahi misteri ciamsi dan pwa pwee (bag.2 tamat). http://web.budaya-tionghoa.net/index.php/item/3818-menjelajahi-misteri-ciamsi-dan-pwa-pwee-bag-2-tamat

Dawan. (5 Juni 2019). Seni Ukir: Pengertian, Jenis, Teknik dan Motifnya. https://ngertiaja.com/seni-ukir/

(20 September 2019). Buddhist Symbolism. https:// en.wikipedia.org/wiki/Buddhist_symbolism

(28 Mei 2019). Kau Chim. https://en.wikipedia.org/wiki/ Kau_chim 